\title{
Preferences of the poor: market participation and asset management of poor households in sixteenth-century Holland
}

\author{
TINE DE MOOR AND JACO ZUIJDERDUIJN \\ Utrecht University, t.demoor@uu.nl
}

\begin{abstract}
Our article aims to detect differences in behaviour towards the capital and land market of households of different sizes and levels of income. Participation in markets for real estate, capital, and ships was considerable, not only among middling and elite groups but also among the poor. Large households were most active in markets, incurring significantly greater debt. Poor households with a low supply of labour were relatively active, purchasing houses and ships, and incurring debts, possibly in order to cope with a lack of parental support. Middling-group households with a low supply of labour primarily sold houses and invested in the capital market, adjusting capital assets to declining labour supply at the end of their life cycle, thus creating cash rents to be able to survive old age.
\end{abstract}

I

Over the past few years, several historians have advanced theories as to how the behaviour of ordinary households altered the course of economic history. De Vries (2008) claims that labour market participation increased because household members had to earn to be able to purchase new luxury products; hitherto, idle hands were put to work. Howell (2010) points to a change in household members' perception of property. Initially, they deemed property to be inalienable, but this changed during the late Middle Ages, allowing property to change hands more easily. De Moor and van Zanden (20I0) suggest that the rise of a new marriage pattern had consequences for both labour market participation and the saving behaviour of household members at all levels of society. What these studies share is the conviction that a change in the preferences of ordinary people was crucial for macro-economic developments.

The idea that over time something changed in the preferences and behaviour of ordinary people is not new, but it remains an important question. There is a large historiography that ascribes a "peasant mentality" to rural populations and uses this to explain the underdevelopment of regions. In this literature, peasant mentality includes a great many elements, including a strong preference for subsistence production and risk-averseness (cf. Ogilvie 200 I for a survey of this literature) that may be summarized as "unenterprising." It follows that its antonym, the "non-peasant mentality" so to speak, may be characterized as "enterprising." Its emergence is usually linked to the transition to early forms of capitalism. ${ }^{\mathrm{I}}$

To study whether this shift in mentality and behaviour indeed occurred over time, and if so, when, is not an easy task. It requires historians to infer in some way the preferences of

\footnotetext{
${ }^{\mathrm{I}}$ Emigh (2004) provides an overview of literature on the transition to capitalism.
} 
ordinary people, and to observe patterns in their behaviour. It thus requires them to study the historical household, which is, as several scholars have pointed out, very much like a "black box," from which it is difficult to see what was going on inside (de Vries 2008, p. 216; Humphries 2010, p. 49). Possibilities for studying the behaviour of ordinary households decrease the further one goes back in time. Whereas historians of the nineteenth century are able to build on detailed case studies, often based on the account books of householders (Morris 2005; Green et al. 2009), historians of the pre-industrial economy either have to concentrate on the asset management of the very wealthy (Degryse 2006) or take recourse to problematic sources such as probate inventories (Deneweth 20II; Ogilvie et al. 20I2). Such studies yield valuable results, but since they provide only snapshots (the moment when the estate of a deceased is recorded), they tell us less about how households dealt with assets during their entire lifetime (McCants 2007, p. 22I).

In this paper, we peek into historical households, using sources that help us to overcome some of the drawbacks discussed above. We do two things: first, we study to what degree poor households participated in markets for real estate and capital, and what types of transactions they made. Were they "unenterprising," only participating in markets out of dire necessity, selling their land and incurring debts? Or were they "enterprising," also buying land on the market and investing savings? Our quantitative study of the poor's behaviour in markets shows that many among them exhibit "enterprising" or "entrepreneurial" behaviour (Section 3). These findings are in line with research into seventeenth- and eighteenthcentury rural populations: Ulrich Pfister provides evidence of peasant households in the Swiss countryside using the land market in a strategic way by adjusting their land and capital assets to their labour capacity (Pfister 2007, pp. 505-13). Sheilagh Ogilvie, Markus Küpker, and Janine Maegraith also suggest that ordinary households in Württemberg, Germany, could make clever use of the market, and not necessarily fall victim to it: "borrowing was not an indicator of crisis or distress," but rather "undertaken as a positive strategy to serve productive purposes" (Ogilvie et al. 2012, p. I36). In an earlier article, Rosenthal (I994) also objected to the widespread idea that rural credit markets only served as a means to expropriate peasants.

Secondly, we study the link between observed behaviour and incentives (Section 4). This is not an easy task: ideally, we would be able to infer incentives from ego documents or interviews with poor people, but these are not available for this early point in time. Instead, we use Ulrich Pfister's interpretation of the permanent income hypothesis (Pfister 2007) to study to what degree households balanced capital assets with labour supply. Pfister based his model on Franco Modigliani's permanent income hypothesis, which deals on a more theoretical level with income flows within the household life cycle. This model is based on the assumption that households tried to stabilize consumption, by saving when they could, and using savings when necessary (Modigliani 1966). Pfister, however, adjusted this model by adding (dis)investing in land to the model - which makes it better suited for pre-industrial societies (Pfister 2007). We apply this model to interpret our empirical data, whereby we use the number of beds reported by householders as a proxy for household labour supply. Our approach allows for a more precise study of pre-industrial portfolio development than is typically found in the literature and also one that includes social groups that usually elude the eye of the historian.

Our study concerns the province of Holland during the sixteenth century: shortly before the Dutch revolt against King Philip II, and also shortly before the Golden Age of the Dutch Republic. This has been identified as a period of transition: smallholders lost their 
land, ${ }^{2}$ causing the rise of proletarians, proto-industries, and wage labour (de Vries I974, pp. 8-9; van Zanden I993; van Bavel 2003). We investigate the market participation and behaviour of poor households in the small town of Edam. Were they "unenterprising" and therefore unable to grasp opportunities, or protect themselves against risk (see Rauch and Frese, 2007)? Or did their behaviour not differ fundamentally from that of wealthy and middling households?

2

The small town of Edam-situated about $20 \mathrm{~km}$ northeast of Amsterdam at the borders of the former Zuiderzee - was part of a highly urbanized region (already in 1462 more than $40 \%$ of its population lived in Edam), with a population dependent on a mixture of activities. Though agriculture was still important, a substantial and rapidly growing part of the workforce was active in fisheries, industries, and trade. ${ }^{3}$ The economy was characterized by smallholding, which was another typical feature of the economy of Holland: most (rural) households owned small plots of land for herding cattle and sold their cattle and dairy products on the market. ${ }^{4}$ Edam was a typical small town, although it may have been relatively wealthy, as becomes clear on the basis of a government inquiry from I5I4 on the revision of tax assessments of towns and villages in the county of Holland (table I). The villages in the surroundings of Edam, an area called De Zeevang, compare quite nicely with other rural settlements in this part of Holland as well, with respect to both population and wealth - although once again, they were relatively wealthy.

Our interest lies in particular with the poor. To study this group, we use tax assessments (Section 3). Since our taxation sources were not solely based on land or home ownership, but also on the possession of such assets as livestock, small savings, and even beds, they should provide an accurate image of the possessions and debts of the poor. In I5I4, the government of Edam explained that "... . whoever comes to live in Edam, even if he [only] rents a bed, is taxed [0.25 lbs], even if he goes around begging" (Boschma-Aarnoudse, 2003, p. 405). ${ }^{5}$ Only in a few instances did the town government decide to assess householders at $\mathrm{O}$ lbs (in 1563 this was the case for only 5 out of I,I47 householders). Of course, getting the poor to actually pay was difficult, so the town government frequently had to remit taxes or settle with lower payments (Boschma-Aarnoudse 2003, pp. 404-5). Such householders struggling to meet their obligations were listed in Edam's tax ledgers though, so we are able to tackle the problem many social historians face, namely the underreporting of the poor in taxation sources.

\footnotetext{
${ }^{2}$ In a recent synthesis, Bas van Bavel states that property relations changed at a relatively early stage in the province of Holland, in the sixteenth century, and later in provinces of the Low Countries. Van Bavel sees this as an important explanatory variable for the rise of the economy of Holland (van Bavel 2010, pp. 242, 259-60).

3 These population figures are based on Boschma-Aarnoudse (2003, pp. 42I-6); cf. economic development $i d e m$, pp. 367-75 and passim.

${ }^{4}$ On the economic history of this region, see van der Woude (I972 pp. 362-3, 457-8, 5I I-3). On the development of the economy of Holland in this period, see de Vries and van der Woude (2000, pp. 236-8), Hoppenbrouwers (200I, pp. 49-50) and van Zanden (2002).

5 The quote is from the Informacie (Fruin I866), a tax survey of the province of Holland, taken in I5I4. Tax assessments in Edam were expressed in pounds and quarters of pounds, which served as a unit of account. In this study we express tax assessments in lbs.
} 
Table I. Relative position of Edam in Holland, I5I4

\begin{tabular}{|c|c|c|c|}
\hline & $\begin{array}{l}\text { Inhabitants (no. of individual } \\
\text { households) }\end{array}$ & $\begin{array}{l}\text { Tax assessment } \\
\text { (lbs) }\end{array}$ & $\begin{array}{l}\text { Taxation } \\
\text { lbs/capita }\end{array}$ \\
\hline Holland & 288,760 & 60,000 & $0.2 \mathrm{I}$ \\
\hline $\begin{array}{l}\text { Edam and } \\
\text { De Zeevang }\end{array}$ & 3,259 & 770 & 0.24 \\
\hline Edam & {$[I, 929]$} & [454] & {$[0.24]$} \\
\hline $\begin{array}{l}6 \text { large towns } \\
\text { (average) }\end{array}$ & II, 550 & 4,248 & 0.38 \\
\hline $\begin{array}{l}22 \text { small towns } \\
\text { (average) }\end{array}$ & 2,128 & 486 & 0.23 \\
\hline De Zeevang & {$[\mathrm{I}, 330]$} & [315] & {$[0.24]$} \\
\hline Warder & 266 & & \\
\hline Middelie & [333] & & \\
\hline Kwadijk & 399 & & \\
\hline Haekswijk & [333] & & \\
\hline Region (average) ${ }^{\mathrm{a}}$ & 600 & I58 & 0.26 \\
\hline
\end{tabular}

Estimates between parentheses.

Note: Since our sources recorded the number of people who received the Holy Communion, we have corrected our figures for the people that did not, i.e. infants and children younger than $13-14$ years. We follow Ad van der Woude's approach, who calculated that c. $33 \%$ of the population must have been younger than I3-I4 years (van der Woude I972, I, pp. 77-85). The differences between these estimates, a population of 3,259 for Edam and De Zeevang in I5I4, and the estimates Boschma-Aarnoudse (2003) based on the verpachtingskohieren (a population of 3,655) seem reasonable-we have to accept a certain margin of error. Since Edam and De Zeevang were one jurisdiction and hence one taxation unit, we have had to estimate the tax assessment for the individual town and villages. We also had to estimate the number of inhabitants for Edam (indicated in the source as between I 400 and I500), as well as Middelie and Haekswijk (both villages were taken together in our source).

Sources: Fruin (I866, pp. I85-9), Fruin (1876, 27I) and Naber (1980).

${ }^{\text {a }}$ Region: I4 villages in the areas Amstelland, Gooiland, De Zeevang, and Waterland for which we have data on population and taxation.

Setting benchmarks to distinguish poor from middling groups is always a bit arbitrary. It is clear that householders set at 0 or $0.25 \mathrm{lbs}$ were poor, for their lack of assets. One of the many poor in Edam was a householder named Ariaen mit een hant (literally: Ariaen with one hand). In 1563, he owned a "small house"-which is likely to have been little more than a shed - and three beds, and was therefore assessed at $0.25 \mathrm{lbs}$. His poverty is furthermore confirmed by the fact he was entitled to poor relief in $\mathrm{I} 58 \mathrm{I}$, when he received bread from the town government. ${ }^{6}$ In her analysis of Edam's taxation sources, Boschma-Aarnoudse explains that a tax assessment of $0.25 \mathrm{lbs}$ generally included a house, beds, perhaps some small savings, and a cow. Land, which was of course a valuable asset in a largely agrarian society, had a relatively strong impact on tax assessments; Boschma-Aarnoudse concludes that the benchmark for landownership lay at $0.25-0.375 \mathrm{lbs}$ (Boschma-Aarnoudse 2003, p. 406). Many smallholders were nevertheless poor: in Edam, we encounter many small plots of land that only sufficed to feed a cow, and even smaller plots only suitable for

\footnotetext{
${ }^{6}$ Waterlands Archief Purmerend, Weeshuizen te Edam: Burgerweeshuis, Armenweeshuis en Protestants Weeshuis, I558-I965 (I970), inv. no. I6.
} 


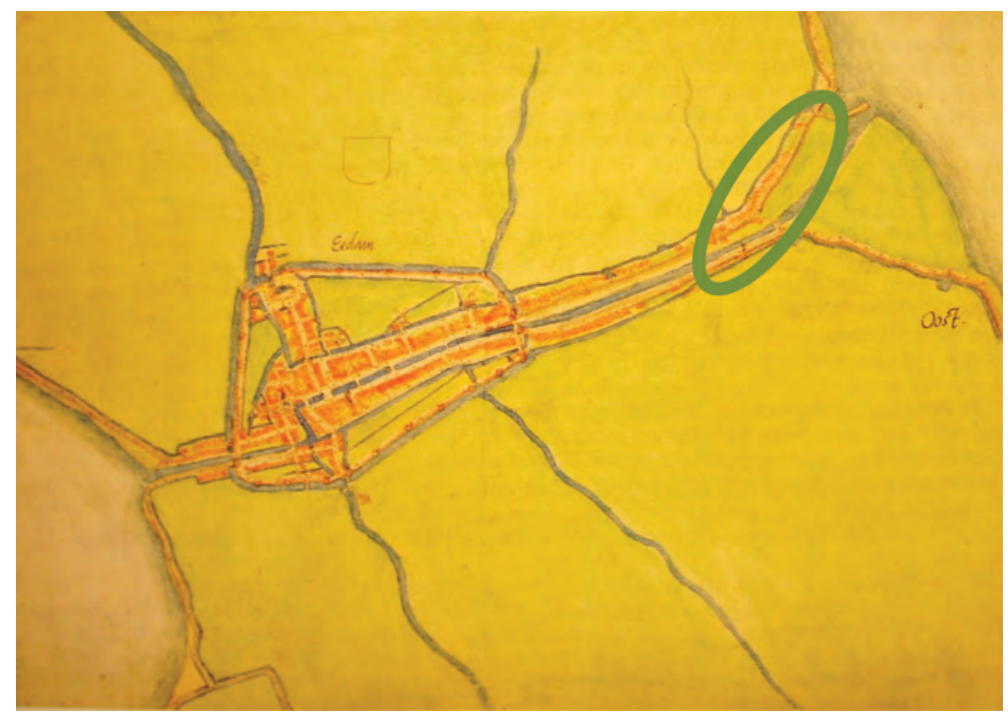

Figure I. Edam c. 1560, map by Facob van Deventer, with indication of the district Oorgat

keeping one calf. ${ }^{7}$ Many of these plots had been divided by inheritance and were no longer sufficient to take care of a cow or calf. Such smallholders were active in small-scale livestock farming aimed at dairy production, bringing butter and cheese to the market, where they bought grain imported from abroad. Clearly, few of them would have been self-sufficient. They had to rely on additional income to make a living, and just like their landless compatriots, they were vulnerable.

This vulnerable position of smallholders can be illustrated with another householder from Oorgat (figure I), Hein Gert Oofs, who was set at $0.5 \mathrm{lbs}$ in taxation in $1563 .{ }^{8} \mathrm{He}$ owned a house and also land: 8.25 morgen (ca. 9 ha). It is impossible to tell exactly what the annual yields from Hein's land were. However, we know that if he had leased it to a tenant, he would have received c. 40 guilders per annum. ${ }^{9}$ This gives us a clue as to what a piece of land this size would yield at minimum. Furthermore, Hein had c. 200 guilders invested in the capital market, which yielded Io guilders per annum. Combined, his possessions probably yielded at least 50 guilders per annum - for comparison, this is the equivalent of around Ioo days' wages of a mason in Amsterdam (Noordegraaf I985, p. 67). It seems safe to say that Hein's possessions did not allow for self-sufficiency; to survive, he had to earn money on the side as a labourer. The same was probably true for most of the households of Edam: in $1563,49 \%$ of the householders were set at $0.25 \mathrm{lbs}$ and were likely to have been landless, and another $27 \%$ were set at $0.25-1.0 \mathrm{lbs}$ and must be considered land-poor. In this respect, the social stratification in Edam did not differ much from that of other small towns in pre-industrial Europe (Alfani 20I0).

\footnotetext{
${ }^{7}$ In the sources, these plots are called coeven (plot of land large enough for one cow) and calfven (plot of land large enough for one calf). Other plots could apparently only be used for cutting reeds (rietlanden).

${ }^{8}$ The 'Oorgat' was an area which consisted of a string of houses to the north of the canal between Edam and the sea. See also the indication on figure $\mathrm{I}$.

${ }^{9}$ Lease prices estimated at five guilders per morgen, based on data from Kuys and Schoenmakers, indicating a rental value of four to six guilders per morgen (Kuys and Schoenmakers I98I, p. 66). A morgen was in this region I.07 ha.
} 
The study of market participation of households often suffers from insufficient data about the people involved. Many scholars have studied markets for land, houses, and capital, particularly in Germany (Baum I985), but without arriving at a good understanding of the social groups involved. The sources they used (Stadtbücher) did not provide clear indicators for the socioeconomic position of participants in exchange. The analysis of contracts recorded by notaries suffers from the same drawbacks. Usually, scholars have to suffice with references to occupation in order to arrive at a rough social classification, with an overrepresentation of elites and middling groups. For instance, Beate Sturm, in her recent book on credit in Hannover, arrives at figures very close to zero with respect to the participation of the Unterschicht in credit markets. ${ }^{\text {IO }}$ But to what degree was this due to a lack of access to credit markets among the poor, or due to a tendency not to record the occupations of the poor in the sources?

We use a register of market transactions, and link the names of participants to taxation sources, and thus arrive at a thorough social stratification of participants in markets for land, houses, financial instruments, and ships. Our data indicate for Edam a far larger participation of the poor than has previously been suggested. The register of market transactions we use in this paper is similar to the aforementioned Stadtbücher and covers I564-67. ${ }^{\text {II }}$ It was kept by the court of Edam, which was responsible for conveyance: transactions involving real estate - including mortgages - only had force of law when they were ratified by the town's aldermen. These transactions were recorded in the aforementioned registers. Transactions not involving real estate could be made without conveyance, but since this would expose the participants to risks, such as reneging and/or moral hazard, they usually decided to go for conveyance (Zuijderduijn 2009). The register thus gives a good impression of market transactions, although we must acknowledge the possibility that some noncollateralized financial instruments or ships were traded without ending up in the register.

We have previously used a smaller sample of this source to make claims about the market volume (van Zanden et al. 2012). To analyse the market participation by poor, middling, and elite groups, we have increased our number of observations and linked the names of participants to the tax register (schotkohier) of 1563 . Of course, this was not without problems: of I,I38 individuals appearing in the register as a contracting party, we were able to establish the tax assessment of 433 (38.1\%). There are several reasons why we were unable to link more participants in market exchange. The main problem is the existence of many people sharing the same first name and surname, in which cases we could not establish a link between the register of market transactions and the tax registers. It is also possible that some of the contracting parties were not householders, but household members. We were unable to link these individuals, since our taxation sources only mention householders. Furthermore, some contracting parties may have established a household after the recording of our taxation source of 1563 or may have moved to Edam after I563. Finally, a considerable

\footnotetext{
${ }^{\text {Io }}$ Among creditors $0.0 \%$, among debtors $0.3 \%$. It should be noted that Sturm was able to establish the occupation of I, 835 out of 4,39I creditors, and I,I 62 out of 4,3I6 debtors. The proportion of participants of who the occupation could not be established, and who therefore may have been part of the lowering groups, is resp. 4 I. $8 \%$ and $26.9 \%$ (Sturm 2009, pp. 65, 8I-3). Other scholars who analysed markets in history also had to deal with large numbers of unidentifiable participants (Baum I972, pp. I72-3).

II This register only begins in I563, so it is only possible to link it up to the taxation sources of I $_{5} 63$.
} 
proportion of the contracting parties did not live in Edam and its surroundings, which also made establishing a link impossible.

We believe that the 433 contracting parties we could link to taxation sources are fairly representative of the larger group of I,I38 participants in markets. Even though we find a considerable participation of the poor, we believe that this is the group that is most likely to suffer from a bias that causes underreporting: since the poor were less likely to report occupations or surnames than middling and elite groups, it is probably more difficult to link them to our taxation sources. Even when we keep this in mind, our results are already strikingly different from earlier studies: it was quite normal for the poor, assessed at $0.25 \mathrm{lbs}$ in taxation, to participate in exchange $(22.9 \%$ of all participants). One step up the ladder, those assessed between 0.25 and I lbs, accounted for $35.5 \%$. Middling groups and elites accounted for 34.4 and $7.2 \%$, respectively (table 2 ). Our approach thus allows us to use tax assessments to investigate the participation in market exchange of the poor - and thus provide a better view than research that used occupations to this end.

As explained in Section I, based on the literature on "peasant mentality," we would expect "unenterprising" poor to have predominantly used the market as a means of last resort, where they could sell off land, or borrow money on collateral. In contrast, "enterprising" poor would also have bought land and invested in the capital market. To understand the behaviour of social groups, table 2 provides a breakdown of sellers/debtors (the "unenterprising") and buyers/creditors (the "enterprising"). The poor (assessed at $0.25 \mathrm{lbs}$ or less) do not appear to have been particularly "unenterprising": whereas they accounted for $22.2 \%$ of all

Table 2. Tax assessments of participants in exchange, 1563-1567 (subdivided into tax categories (lbs)

\begin{tabular}{|c|c|c|c|c|c|}
\hline & 0.25 & $>0.25-\mathrm{I}$ & $>_{\mathrm{I}-4}$ & $>_{4}$ & Total N \\
\hline & \multicolumn{5}{|c|}{ "Unenterprising" (seller/debtor) (\%) } \\
\hline Land & 20 & 45 & 30 & 5 & 40 \\
\hline Houses & 25 & 36.8 & 35.5 & 2.6 & 76 \\
\hline Ships & $\mathrm{I} 5.2$ & 25.8 & 51.5 & 7.6 & 66 \\
\hline Lijfrenten & $7 \cdot 7$ & 23.1 & 53.8 & I5.4 & I3 \\
\hline Losrenten & 31.9 & 40.3 & 22.2 & 5.6 & 72 \\
\hline Other debts & 0 & 50 & 50 & 0 & 2 \\
\hline \multirow[t]{2}{*}{ Total } & 22.7 & $35 \cdot 7$ & 36.1 & 5.6 & 269 \\
\hline & \multicolumn{5}{|c|}{ "Enterprising" (buyer/creditor) (\%) } \\
\hline Land & 5.9 & $35 \cdot 3$ & $4 \mathrm{I} .2$ & I7.6 & 34 \\
\hline Houses & 29 & 32.7 & 29.I & 9.I & 55 \\
\hline Ship & 52.9 & $4 \mathrm{I} .2$ & 5.9 & 0 & I7 \\
\hline Lijfrenten & 0 & 25 & 50 & 25 & 4 \\
\hline Losrenten & I9.6 & 37 & 37 & 6.5 & 46 \\
\hline Other debts & $33 \cdot 3$ & $33 \cdot 3$ & 0 & $33 \cdot 3$ & 3 \\
\hline Total & 23.3 & 35.2 & $3 \mathrm{I} .5$ & IO.I & I59 \\
\hline Grand total & 22.9 & $35 \cdot 5$ & 34.4 & 7.2 & 428 \\
\hline
\end{tabular}

Note: Total of I,I38 participants in exchange; we were able to link 433 participants to tax assessments. Furthermore, several people, mainly from middling groups and the elite, participated on more than one occasion - for instance the wealthy Jan Jansz. Brasker, who was assessed at $10.625 \mathrm{lbs}$ in taxes, participated in four transactions. The number of unique participants is therefore lower than $\mathrm{I}, \mathrm{I} 38$.

Source: Waterlands Archief, Oud Rechterlijk Archief Edam, inv. no. 3,813. 
sellers/debtors, they also accounted for $22.7 \%$ of all buyers/creditors. The market participation of the poor was thus rather balanced, and the same goes for the smallholders (assessed at $>0.25-\mathrm{I} \mathrm{lbs}$ ), who accounted for $34.8 \%$ of sellers/debtors, and $36.8 \%$ of buyers/creditors. Middling groups $\left(>_{\mathrm{I}}-4 \mathrm{lbs}\right)$ and elites $\left(>_{4} \mathrm{lbs}\right)$ also do not show a clear pattern of behaviour.

This finding seems to support the literature indicating active market participation among the poor (Rosenthal I994; Pfister 2007), who certainly did not only sell real property and incur debts in the market, but also bought real property and invested in financial instruments. Of course, we should not ignore the fact that the poor were probably active in low-end transactions, whereas elite groups would have been active in high-end transactions. However, the point we want to make here is not about the wealth of the poor but about their participation in market exchange, and as far as we know, this is the first time this has been supported with empirical evidence, at least for the early modern period.

\section{4}

Economic theory suggests market participation allows householders to cope with difficulties related to the household life cycle (Modigliani I966). Historians have also suggested that possibilities to invest and disinvest in capital markets allowed households to overcome difficulties in setting up a household, as well as surviving old age (Di Matteo I997; De Moor and van Zanden 20I0; Lilja and Bäcklund 20I3). Pfister (2007) has suggested that markets also allowed households to balance labour supply and capital assets. Labour supply fluctuated during the household life cycle. Most households started out as units consisting of a man and woman. The latter's labour supply quickly decreased due to pregnancies, birthing, and child care. In the early stages of the household life cycle, the number of consumers also exceeded the number of producers. This unfavourable situation came to an end once the wife stopped having children and the children had grown old enough to participate in farm work and proto-industry. According to Pfister (2007), to make the best use of this increasing labour supply, households invested in land and capital assets, such as tools. Later on, when children left the parental household to work as servants, or to marry, labour supply decreased again. Consequently, land and physical capital were sold; the profits could be used to safeguard old age, by creating a steady income from investments in the capital market.

Here, we use Pfister's model to study whether the households of Edam might have used markets to cope with fluctuations in the supply of labour. In his article, Pfister creates a model of the life cycle of investment and disinvestment:

[w] hereas the young (age group 20-29) tended to buy rather than sell land and houses, sales progressively outweighed purchases with increasing age. Among those aged 50 and above, sales averaged more than three times the amount of purchases. This finding reflects a conversion of land into financial capital, producing a cash rent during a life stage characterized by a declining capacity for physical work (Pfister 2007, p. 510).

Pfister also observes differences between social classes: farmers inherited large plots of land and therefore did not have to purchase. They do show a tendency to sell land, supposedly to deal with crises, such as the death of a spouse, or the obligation to compensate heirs. A second group, consisting of households combining farm work with proto-industry, was 
much more active in purchasing land. They started out with "substantial purchases" at the formation of the new household and then relaxed investments in land (because of low labour supply), before beginning to purchase land again once labour supply increased. According to Pfister, this happened in the 40-49 age range. The "lower class" particularly purchased land in the early stages of the household life cycle, after which they gradually sold their land again. According to Pfister, this group ended up selling land out of poverty during old age, rather than to create cash rents (Pfister 2007, pp. 5II-2).

To what degree do the households of Edam fit this model? To answer this, we require an indicator for the labour supply of households that participated in markets, 1564-67. To this end, we use reports of the number of beds in our 1563 taxation source and thus distinguish households with a low and high supply of labour. We know that, on average, I.8 individuals shared a bed, ${ }^{\mathrm{I} 2}$ and assume that young children slept either in cribs or in bed with their parents. Only elder children would have required additional beds that would have been reported to tax assessors. We believe that reports of more than one bed should therefore be interpreted as a sign of the presence of children aged around 5-6 years and above, or other co-residents.

Furthermore, to be useful as an indicator of household labour supply, the number of beds should change over time. Case studies into the development of the property of householders in 1546 , I553, and 1563 confirm that this happened. ${ }^{13}$ We are generally unaware of how householders acquired and alienated beds; they may have bought and sold new and secondhand beds or received beds and given them away. It is imaginable that parents gave beds to children who left to establish their own households. Since beds were quite valuable (McCants 2007, pp. 225-7), we also have to address the question whether the number of beds reflect labour supply in households, or differences in wealth levels. Did wealthier households have more possibilities to purchase them? Table 3 shows the average tax assessments for householders reporting various numbers of beds. The average for households reporting one bed $(0.89 \mathrm{lbs})$ does not differ markedly from that of households reporting two, three, or four beds (0.9I, 0.88 , and $0.88 \mathrm{lbs}$, respectively). ${ }^{\mathrm{I} 4} \mathrm{~A}$ further statistical analysis confirmed that there is no reason to believe that wealth levels had much of an effect on the number of beds reported. ${ }^{\mathrm{I}}$

Finally, at what age did children begin to supply labour to the household? At least from the seventeenth century onward, child labour was fairly common; children of the poor started working as early as six years old (Van Nederveen Meerkerk and Schmidt 2008, p. 72I), and sixteenth-century data for the poor in the surroundings of the town of Leiden show a similar pattern (Posthumus I912, p. 8). In Edam, children might have helped in livestock holding and dairying, which probably ranked as the most important home industry. In spite of its urban charter, the town was characterized by many smallholding families. In $1563,45.6 \%$ of the town's households owned land, and $24.4 \%$ owned livestock. In the

${ }^{12}$ In 1563, householders in Edam and De Zeevang reported 3,I73 beds, or 2.2 beds per household on average. Considering population estimates for Edam and De Zeevang of 5,765 (Boschma-Aarnoudse 2003, pp. 425-6) we arrive at c. I.8 persons per bed.

${ }^{13}$ For fifteen households we were able to link, six reported different numbers of beds in our sample years. This indicates that beds were bought, received, and built once the household expanded, and sold or given away once the number of members declined.

${ }^{\text {I4 }}$ Average tax assessments of householders reporting either zero, or more than four beds, show greater differences, but these are probably due to a far smaller number of observations.

${ }^{15} \mathrm{~A}$ regression analysis of number of beds and tax assessments showed an correlation coefficient ( $\mathrm{r}$ ) of 0.00763 and a determination coefficient $\left(\mathrm{r}^{2}\right)$ of 0.0000582 , which indicates a very weak correlation between the two. 
Table 3. Beds/tax assessment (per category of tax, in guilders)

\begin{tabular}{lcccccll}
\hline \hline Beds & $<0.25$ & 0.25 & $>0.25-\mathrm{I}$ & $>\mathrm{I}-4$ & $>_{4}$ & Average & Median \\
\hline 0 & 5 & IO & 5 & 5 & 0 & 0.63 & 0.25 \\
$\mathrm{I}$ & IO & I57 & I33 & 75 & I2 & 0.89 & 0.375 \\
2 & $\mathrm{I} 9$ & 233 & 207 & $\mathrm{I} 39$ & $\mathrm{I} 8$ & $0.9 \mathrm{I}$ & 0.5 \\
3 & $\mathrm{IO}$ & $\mathrm{I} 23$ & $\mathrm{I} 00$ & 74 & 8 & 0.88 & 0.375 \\
4 & 4 & 27 & 42 & 24 & 2 & 0.88 & 0.625 \\
5 & 0 & 9 & 3 & 2 & 2 & $\mathrm{I} . \mathrm{I} 6$ & 0.25 \\
$>5$ & 0 & 6 & 5 & 2 & $\mathrm{I}$ & 0.63 & 0.375 \\
\hline \hline
\end{tabular}

Note: All households: I,472. Excluded are a limited number of households claiming to own half a bed etc.

surrounding villages, these figures were higher, of course, at 81.9 and $76.5 \%$, respectively (Boschma-Aarnoudse 2003, pp. 473 and 477) ${ }^{{ }^{16}}$ Although livestock holding was not very labour-intensive, butter and cheese production were, and it does not seem unreasonable to believe these activities depended on the labour input of women and children. Altogether, even though we have to accept a margin of error, we believe the number of beds to be a good indicator of household labour supply.

\section{5}

In our analysis, we first of all distinguish low-labour-supply households, reporting zero to one bed in 1563 . We assume these households consisted of one or two adults, and possibly also of young children unable to work. As a second category, we distinguish high-labour-supply households, reporting two beds or more. We assume these consisted of at least one adult and children old enough to work. This category may also have included various relatives or even non-kin.

What type of behaviour would we expect from householders? Some of the low-labour-supply households would have been at the very beginning of the household life cycle, such as newlyweds with young children. According to Pfister (2007), these were likely to purchase land and a house; considering the practice of neolocality in Edam, we would certainly expect newlyweds to have purchased houses. Other low-labour-supply households were in the final stages of their household life cycle. Such households would have responded to decreasing labour supply by selling land and using the revenues to invest in "cash rents" - in Edam, this would have meant investing in life annuities or redeemable annuities (Zuijderduijn and De Moor 20I3). High-labour-supply households would have been more active in markets. To cope with fluctuations in the supply of labour - due to children reaching an age at which they could contribute, and wives being able to work more once the children were participating in household labour - they had to adjust their capital assets. To enable these investments, high-labour-supply households would have invested in land and capital assets, and not in cash rents.

To what degree do we see these patterns among low- and high-labour-supply households in Edam? We provide a summary of our findings. We were able to find data for the number of

${ }^{16}$ Boschma-Aarnoudse (2003, p. 254) estimated that the area may have produced 35,000 kg of cheese and 50,000 kg of butter per annum in the mid-sixteenth century. 
Table 4. Percentage of a specific type of transaction per tax category in the group of low-labour-supply households ( $O-I$ beds)

\begin{tabular}{|c|c|c|c|c|c|c|c|}
\hline \multirow[b]{2}{*}{ Lbs } & \multicolumn{2}{|c|}{ Capital market (\%) } & \multicolumn{3}{|c|}{ Real estate market $(\%)$} & \multicolumn{2}{|c|}{ Commodities (\%) } \\
\hline & Life annuity & $\begin{array}{l}\text { Redeemable } \\
\text { annuity }\end{array}$ & Houses & Land & Other & Ships & Other \\
\hline \multicolumn{8}{|c|}{ Investors (creditor/buyer) } \\
\hline 0.25 & 0 & $\mathrm{I} .2^{\mathrm{a}}$ & 3.0 & 0.6 & o & 3.0 & o \\
\hline$>0.25^{-}$ & o & $4 \cdot 4$ & 0.7 & I.5 & 0.7 & 2.2 & o \\
\hline \multicolumn{8}{|l|}{ I } \\
\hline$>\mathrm{I}-4$ & o & 3.8 & o & I. 3 & 0 & 0 & 0 \\
\hline$>_{4}$ & 0 & 0 & 8.3 & 8.3 & o & o & o \\
\hline \multicolumn{8}{|c|}{ Sellers (debtor/seller) } \\
\hline 0.25 & o & 2.4 & I. 8 & 0.6 & 0 & ० & o \\
\hline$>0.25^{-}$ & o & 0 & 2.9 & I.5 & 0.7 & 0.7 & 1.5 \\
\hline \multicolumn{8}{|l|}{ I } \\
\hline$>\mathrm{I}-4$ & $\circ$ & o & 3.8 & 2.5 & $\circ$ & ० & o \\
\hline$>4$ & 0 & 0 & 0 & 0 & 0 & 0 & 0 \\
\hline
\end{tabular}

${ }^{a}$ Example of how to read this table: "I. $2 \%$ of the households with a low labour supply that paid $0.25 \mathrm{lbs}$ in tax invested in a redeemable annuity."

beds reported by the 382 participants in exchange. Households reporting zero or one bed participated 52 times, households reporting more than one bed 330 times. To get a better idea of what these figures mean, we have expressed the number of low- and high-labour-supply households as a percentage of the total number of those households. Thus, in 1564-67, 52 low-labour-supply households participated in markets, out of a total of 946 households in Edam and De Zeevang reporting zero to one bed in 1563; we express this as participation of $5.5 \%$. In contrast, high-labour-supply households participated on 330 occasions, which constitutes $13.5 \%$ of the total 2,452 households reporting more than one bed in 1563 . The latter category was thus more than twice as likely to participate in markets, a result that links up nicely with Pfister's model of households having to adjust capital assets to labour supply by means of selling and buying, and borrowing and lending (Pfister 2007).

Taken as a whole, low-labour-supply households were not very active in capital markets as debtors (table 4). This is in line with Pfister's model: at the beginning of the life cycle, such households would have had prior opportunity to save for purchases (Pfister 2007). In contrast, high-labour-supply households were much more likely to contract debts (table 5), which hints at requirements to increase their stock of capital at a time when eventual savings would already have been exhausted. It is worthwhile to point out that they were also relatively active in selling life annuities (table 5), which might hint at requirements to settle inheritances with other heirs (Pfister 2007, p. 5II).

Rather than participating in the capital market, low-labour-supply households were more active in selling and buying. The land market was not unimportant but does not really standout (see table 4). This is also true for high-labour-supply households (table 5). This is certainly less activity than we expected based on the idea that households had to purchase and 
Table 5. Percentage of a specific type of transaction per tax category in the group of high-labour-supply ( $>_{I}$ beds)

\begin{tabular}{|c|c|c|c|c|c|c|c|}
\hline \multirow[b]{2}{*}{ Lbs } & \multicolumn{2}{|c|}{ Capital market (\%) } & \multicolumn{3}{|c|}{ Real estate market (\%) } & \multicolumn{2}{|c|}{ Commodities (\%) } \\
\hline & $\begin{array}{l}\text { Life } \\
\text { annuity }\end{array}$ & $\begin{array}{l}\text { Redeemable } \\
\text { annuity }\end{array}$ & House & Land & Other & Ship & Other \\
\hline \multicolumn{8}{|c|}{ Investors (creditor/buyer) } \\
\hline 0.25 & 0 & 2.0 & 3.0 & I. 3 & 0.3 & I. 3 & 0.3 \\
\hline$>0.25-\mathrm{I}$ & o & 3.6 & 4.2 & 2.5 & o & I.I & 0.3 \\
\hline$>\mathrm{I}-4$ & o & 9.I & 6.2 & 4.2 & $\circ$ & 0 & 0.2 \\
\hline$>_{4}$ & 3.2 & 6.5 & 9.7 & I6.I & $\circ$ & $\circ$ & $\circ$ \\
\hline \multicolumn{8}{|c|}{ Sellers (debtor/seller) } \\
\hline 0.25 & 0.3 & 4.5 & 2.5 & 0.3 & o & 2.0 & o \\
\hline$>0.25-\mathrm{I}$ & 0.8 & $7 \cdot 3$ & $3 \cdot 9$ & $3 \cdot 9$ & 0.3 & 4.2 & $\circ$ \\
\hline$>\mathrm{I}-4$ & 2.9 & 7.1 & 9.I & $3 \cdot 7$ & 0.2 & I4.I & $\circ$ \\
\hline$>_{4}$ & 3.2 & 12.9 & 0 & 6.5 & 3.2 & 9.7 & 3.2 \\
\hline
\end{tabular}

sell land to balance capital assets and labour supply. ${ }^{17}$ But, perhaps in Holland, lease markets were a viable alternative for households looking to extend production by means of livestock holding. ${ }^{18}$

Table 4 indicates that low-labour-supply households were more active in selling houses. We interpret this as an activity that must be linked to the end of the life cycle rather than to the beginning. It is in line with Pfister's assertion that to survive, many of the poor had to sell property over time (Pfister 2007). ${ }^{19}$ However, high-labour-supply households were also relatively active in the housing market. The housing market thus was not the exclusive domain of low-labour-supply households buying to start their own household, or selling to cope with a reduced supply of labour; it was also used by large households that apparently moved around with their children. ${ }^{20}$

Finally, high-labour-supply households show a tendency to sell ships. Shipbuilding was one of the most important crafts of Edam: the town produced 40-50 new ships per year (Boschma-Aarnoudse 2003, pp. 43I-3). It was also a labour-intensive craft, ${ }^{2 \mathrm{I}}$ which may explain the predominance of large households. However, there was also a market for secondhand ships, with 24.5 ships being sold in $1564-65$. Although ageing shipmasters and fishermen would appear the most likely to sell their boats, the score for low-labour-supply households selling ships is quite low, at $0.7 \%$.

${ }^{17}$ It is in line with the move away from investing in many scattered pieces of land as observed in Zuijderduijn and De Moor (2013).

${ }^{18}$ In the sixteenth century, many improvements were made with respect to the property rights of landlords (van Bavel et al. 2013).

I9 This does raise the question where the elderly went to live themselves. It seems they may have rented a room or moved in with relatives, and some might even have bought a corrody in Edam's newly founded proveniershuis, which was a sort of boarding house for elderly people.

${ }^{20}$ This high spatial mobility is also visible in our taxation sources: many households initially found in one location had disappeared by the next year these sources were recorded.

${ }^{21}$ Of the shipbuilders Boschma-Aarnoudse identified (2003, pp. 43I-3), and whom we could link to our taxation sources, only one belonged to the low-labour-supply category (Dirck Taemsz., who sold three ships in I564-65, reported one bed). Sixteen households reported more than one bed, and thus had a high labour supply. 
To summarize, high-labour-supply households were more active in markets. Their behaviour mirrors Pfister's model in the sense that they were likely to incur debts, and also bought and sold land (Pfister 2007). Even so, they were most active in buying and selling houses, which seems to suggest that in Edam moving may also have been an important means of adjusting capital assets to household labour supply. It is more difficult, however, to fit low-labour-supply households into the model. Contrary to what we expected, these were more likely to sell houses than to buy them, and they also do not feature prominently as investors in capital markets.

We believe that part of the solution lies in the specific behaviour of various social groups. Tables 4 and 5 provide data on market behaviour of low- and high-labour-supply households from different wealth categories. When we look at small households, the poor score relatively high in the categories of buying ships and houses. We interpret these purchases as activities at the beginning of the life cycle. Our data suggest that at this stage the poor were more likely than other groups to purchase houses and ships; this was not so among high-labour-supply households. It is difficult to give an explanation for this. It may hint at low intergenerational support from poor parents to their children, who had to purchase houses and ships themselves. Parents from middling groups and elites may have provided much more, through gifts and inheritances, to their children. This might have had two effects: first, "starters" coming from middling groups and elites were already relatively wealthy at marriage, and secondly, they did not immediately have to participate in the market to purchase capital assets.

Another thing that stands out is the poor's relatively high score in incurring debts in the low-labour-supply stage $(2.4 \%)$. In this, they differ from wealthier households, who did not incur many debts in the low-labour-supply stage, but did so in the high-labour-supply stage. Even though we cannot be entirely sure about whether the poor incurred these debts at the beginning or end of the life cycle, it makes sense to link this to their early investments. If this reading is correct, the poor usually financed houses and ships by borrowing in the capital market. They could do so by taking out a mortgage on the house or ship they were buying to secure a redeemable annuity.

When we continue to look at the low-labour-supply stage, but now focus on wealthier households (categories $>0.25-\mathrm{I}$ lbs and $>\mathrm{I}-4 \mathrm{lbs}$ ), we see that they seem to have done exactly the opposite. They score high in selling capital assets and investing in redeemable annuities. It makes sense to link this to the end of the life cycle, and regard this as households selling capital assets and using the profits to create cash rents (Pfister 2007, pp. 5II-I2). We should also stress that this mechanism may not have been exclusive to the end of the life cycle, as selling capital assets and investing in redeemable annuities was also quite common for high-labour-supply households.

Taken together, the poor seem to have behaved slightly differently from middling groups and elites. Particularly as creditors and buyers they are exceptional in the sense that small and large households show more or less the same level of activity. As pointed out before, in general large households were the most active in markets (table 5). The poor were most likely to invest at the beginning of the household life cycle, something also predicted by Pfister. He sees limited possibilities for the poor to keep up with investing at later stages, and a general move towards selling capital assets (Pfister 2007). The latter is not observed in Edam though, where large, poor households were about as likely to invest as small ones. 


\section{6}

Inferring preferences of householders from historical sources remains a problematic exercise. To what degree they could act strategically, or merely followed established patterns remains debatable (Fontaine and Schlumbohm 2000, p. 7). And if householders did pursue strategies, there were many things that could have ruined their intentions: also in the sixteenth century, life was what happened while people were making plans. Nevertheless, we believe that some of our results are in line with Pfister's (2007) model for household strategies, and can therefore tell us something about how households in Edam preferred to make use of their access to markets.

Our data suggest that households with a high supply of labour participated more in markets than households with a low supply of labour, both absolutely and relatively speaking. We interpret this finding as a consequence of frequently having to adjust capital assets to fluctuations in labour supply of households, which depended on loans to finance this; as a result, high-labour-supply households were more likely to incur debts than low-labour-supply households. However, whereas we might have expected that land was an important means of balancing capital assets and labour, as it should have allowed households to increase and decrease livestock holding and dairying, the exchange of land was not very prominent in Edam. Could the increasing popularity of lease markets, as indicated by van Bavel et al. (2013), have allowed households to make less use of land markets in dealing with fluctuations in labour supply? Instead of buying and selling land, high-labour-supply households were very active in exchanging houses. Future research should reveal whether this was a matter of adjusting home industry space to labour supply, or merely of adjusting housing to family size.

Our analysis of the market activity of different wealth groups reveals a few other mechanisms. The behaviour of poor low-labour-supply households stands out in the sense that they were likely to invest in houses and ships, and to incur debts. We interpret this as the result of the poor being forced to enter markets at the beginning of the life cycle to purchase the capital assets they needed to make a living. Wealthier households may have received such capital assets from parents, as a gift or inheritance, and could thus postpone making such investments.

Wealthier households in the low-labour-supply stage were likely to sell capital assets and invest in the capital market. If we are correct in linking this behaviour to the end of the life cycle, this observation would indicate that households were selling capital assets once household labour supply declined, and investing the revenues in cash rents. However, we should stress that similar transactions are also likely to have occurred at earlier stages in the life cycle: high-labour-supply households, too, were very active in selling houses and land, and investing in capital markets. This observation is not in line with Pfister's (2007) model, which assumes a development over time from investing in capital assets to investing in cash rents at the end of the life cycle. A possible reason for this is that financial instruments served as an important means to finance large purchases, such as land, houses, and ships.

The wider significance of these findings lies with our perception of the agency of poorer households and their behaviour towards markets of all sorts. Whereas studies mentioned earlier were rather pessimistic about the potential of poor households to participate or even contribute to economic development, and described the poor as a rather dependent group, their activities on the Edam markets for the exchange of assets and capital shows a more pro-active behaviour, or at least a behaviour that reacted to changes in the household life cycle stages they were in at that point. As such, the poor expressed their preferences, 
which demonstrates that a certain level of agency can be expected at all levels of society, if markets are sufficiently accessible. Elsewhere we have already demonstrated that the early modern Dutch markets were accessible, for various classes within society, and for both sexes (see De Moor et al. 2009; van Zanden et al. 2012). It remains hard to pinpoint the exact origins of this behaviour in the past, and whether this behaviour is to be expected in all societies with sufficiently accessible markets, but many authors, cited at the beginning of this article, have already convincingly argued that such micro-changes may have had a macro-impact on the economy and society of their times.

\section{Funding}

The research for this article was made possible by funding from the European Research Council under the European Community's Seventh Framework Programme (FP7/ 2007-2013)/ERC grant agreement no. 240928) as part of the project "United we stand. The dynamics and consequences of institutions for collective action in pre-industrial Europe." See also http://www.collective-action.info.

Conflict of interest statement. None declared.

\section{References}

AlfaNi, G. (20I0). Wealth inequalities and population dynamics in early modern northern Italy. fournal of Interdisciplinary History 40, pp. 513-49.

Baum, H.-P. (1972). Hochkonjunktur und Wirtschaftskrise im spätmittelalterlichen Hamburg. Hamburger Rentengeschäfte I37I-I4IO. Hamburg: Hans Christians.

Baum, H.-P. (1985). Annuities in late medieval Hanse towns. Business History Review 59, pp. 24-48.

Boschma-Aarnoudse, C. (2003). Tot verbeteringe van de neeringe deser stede: Edam en de Zeevang in de late middeleeuwen en $16^{\text {de }}$ eeuw. Hilversum: Verloren.

Degryse, K. (2006). De Antwerpse fortuinen: kapitaalsaccumulatie, -investering en - rendement te Antwerpen in de I8de eeuw. Bijdragen tot de Geschiedenis LXXXVIII. Antwerpen: Universiteit Antwerpen, Centrum voor stadsgeschiedenis, Genootschap voor Antwerpse geschiedenis.

De Moor, T. and van Zanden, J.L. (2010). Girl power. The European marriage pattern (EMP) and labour markets in the North Sea region in the late medieval and early modern period. Economic History Review 63, pp. I-33.

De Moor, T., Zuijderduijn, C.J. and van Zanden, J.L. (2009). Micro-credit in late medieval waterland. households and the efficiency of capital markets in Edam en De Zeevang, I462-1563. In S. CAvaciocchi (ed), La famiglia nell'economia europea. Secc. XIII-XVIII/The Economic Role of the Family from the 13th to the I8th Centuries. Firenze: Firenze University Press, pp. 65I-68.

Deneweth, H. (20II). A fine balance. Household finance and financial strategies of Antwerp households, I7th-18th century. Tijdschrift voor Sociale en Economische Geschiedenis 8, pp. I5-43.

DE VRIES, J. (1974). The Dutch Rural Economy in the Golden Age, I500-I700. London: Yale University Press.

DE VRIES, J. (2008). The Industrious Revolution. Consumer Behaviour and the Household Economy, I650 to the present. Cambridge: Cambridge University Press.

DE VRIes, J. and van DeR Woude, A. (2000). The First Modern Economy. Success, Failure, and Perseverance of the Dutch Economy, I500-I815. Cambridge: Cambridge University Press.

Di Matteo, L. (1997). Wealth accumulation and the life-cycle in economic history: implications of alternative approaches to data. Explorations in Economic History 35, pp. 296-324. 
Emigh, R.J. (2004). [The] transition(s) to capitalism(s)? A review essay. Comparative Studies in Society and History 46, pp. I88-98.

Fontaine, L. and Schlumbohm, J. (2000). Household strategies for survival: an introduction. International Review of Social History 45(Suppl. S8), pp. I-I7.

FRUIN, R.J. (I866). Informacie up den staet faculteyt ende gelegentheyt van de steden ende dorpen van Hollant ende Vrieslant, om daernae te reguleren de nyeuwe schiltaele. Gedaen in den jaere 15I4. Leiden: A.W. Sijthoff.

FruIN, R.J. (1876). Enqueste ende Informatie upt Stuck van der Reductie ende Reformatie van den Schiltaelen, voertijts getaxeert ende gestelt geweest over de landen van Hollant ende Vrieslant : gedaen in den jaere I494. Leiden: Brill.

Green, D.R., Owens, A., Maltby, J. and Rutterford, J. (2009). Lives in the balance? Gender, age and assets in late-nineteenth-century England and Wales. Continuity and Change 24, pp. 307-35.

Hoppenbrouwers, P.C.M. (200I). Mapping an unexplored field: the Brenner debate and the case of Holland. In P.C.M. Hoppenbrouwers and J.L. van ZAnden (eds) Peasants into Farmers? The Transformation of Rural Economy and Society in the Low Countries (Middle Ages-19th Century) in the Light of the Brenner Debate. Turnhout: Brepols, pp. 4I-66.

Howell, M.C. (2010). Commerce before Capitalism in Europe, 1300-1600. Cambridge: Cambridge University Press.

Humphries, J. (2010). Childhood and Child Labour in the British Industrial Revolution. Cambridge: Cambridge University Press.

KuYs, J. and Schoenmakers, J.T. (I98I). Landpachten in Holland, I500-I650. Amsterdam: Historisch seminarium van de Universiteit van Amsterdam.

LiljA, K. and BäCKLUND, D. (2013). To navigate the family economy over a lifetime: life-cycle squeezes in pre-industrial Swedish towns. European Review of Economic History 17, pp. I71-189.

McCants, A.E.C. (2007). Goods at pawn. The overlapping worlds of material possessions and family finance in early modern Amsterdam. Social Science History 3I, pp. 213-38.

Modigliani, F. (I966). The life cycle hypothesis of saving, the demand for wealth and the supply of capital. Social Research 3I, pp. I60-2I7.

Morris, R.J. (2005). Men, Women and Property in England, I780-I870: A Social and Economic History of Family Strategies amongst the Leeds Middle Classes. Cambridge: Cambridge University Press.

NABER, J.C. (I980). Een terugblik: statistische bewerking van de resultaten van de Informacie van I5I4. Haarlem: Stichting Contactcentrum voor regionale en plaatselijke geschiedbeoefening in Noorden Zuid-Holland.

NoordegraAf, L. (1985). Hollands welvaren? Levensstandaard in Holland, I450-I650. Bergen: Octavo.

OGILvie, S. (200I). The economic world of the Bohemian Serf: economic concepts, preferences, and constraints on the estate of Friedland, I583-I692. Economic History Review 54, pp. 430-53.

Ogilvie, S., Küpker, M. and Maegraith, J. (20I2). Household debt in seventeenth-century Württemberg: evidence from personal inventories. Fournal of Economic History 72, pp. 134-68.

PFister, U. (2007). Rural land and credit markets, the permanent income hypothesis and protoindustry: evidence from early-modern Zurich. Continuity and Change 22, pp. 489-518.

Posthumus, N.W. (I912). Een zestiende-eeuwsche enquete naar de buitenneringen rondom de stad Leiden. Bijdragen en Mededeelingen van het Historisch Genootschap 33, pp. I-95.

RAUCH, A. and FRESE, M. (2007). Let's put the person back into entrepreneurship research: a meta-analysis on the relationship between business owners' personality traits, business creation, and success. European fournal of Work and Organizational Psychology 16, pp. 353-85.

Rosenthal, J.-L. (1994). Rural credit markets and aggregate shocks: the experience of Nuits St. Georges, I756-I776. Economic History Review 54, pp. 288-306.

Sturm, B. (2009). Wat ich schuldich war. Privatkredit im frühneuzeitlichen Hannover (1550-1750). Stuttgart: Franz Steiner.

VAN BAVEL, B. (2003). Early proto-industrialization in the low countries? The importance and nature of market-oriented non-agricultural activities in the countryside in Flanders and Holland, c. I250-I570. Revue Belge de Philologie et d'Histoire 81, pp. II09-65. 
van Bavel, B. (20I0). Manors and Markets. Economy and Society in the Low Countries, 500-I60o. Oxford: Oxford University Press.

van Bavel, B., Kuijpers, E., Dijkman, J. and Zuijderduijn, J. (2013). The organisation of markets as a key factor in the rise of Holland from the fourteenth to the sixteenth century: a test case for an institutional approach. Continuity and Change 27, pp. 347-78.

van Der Woude, A.M. (1972). Het Noorderkwartier. Een regionaal historisch onderzoek in de demografische en economische geschiedenis van westelijk Nederland van de late middeleeuwen tot het begin van de negentiende eeuw. Wageningen: H. Veenman \& Zonen.

Van Nederveen Meerkerk, E. and Schmidt, A. (2008). Between wage-labor and vocation. Child labor in Dutch urban industry, I600-I800. Fournal of Social History 41, pp. 717-36.

van Zanden, J.L. (1993). The Rise and Decline of Holland's Economy: Merchant Capitalism and the Labour Market. Manchester: Manchester University Press.

van ZANDEN, J.L. (2002). Taking the measure of the early modern economy: historical national accounts for Holland in I5IO-I5I4. European Review of Economic History 6, pp. I3I-63.

van Zanden, J.L., Zuijderduijn, J. and De Moor, T. (20I2). Small is beautiful: the efficiency of credit markets in the late medieval Holland. European Review of Economic History 16, pp. 3-23.

Zuijderduijn, C.J. (2009). Medieval Capital Markets. Markets for 'renten', State Formation and Private Investment in Holland (I300-I550). Leiden/Boston: Brill.

Zuijderduijn, J. and DE Moor, T. (2013). Saving, spending or investing? Risk management of sixteenth-century Dutch households. Economic History Review 66, pp. 38-56. 